\title{
Effect of Organic and Inorganic Amendments on the Phytoavailability of Phosphorus to Corn (Zea mays)
}

\author{
Mejbah Uddin, Abul Kashem*, Khan Towhid Osman
}

Department of Soil Science, University of Chittagong, Chittagong, Bangladesh.

Email: *kashem00@yahoo.com

Received December 29 $9^{\text {th }}, 2011$; revised January $30^{\text {th }}, 2012$; accepted February $8^{\text {th }}, 2012$

\begin{abstract}
A pot experiment was conducted to investigate the effect of cow manure, city waste, chicken manure and TSP on the growth of corn (Zea mays) and phytoavailability of phosphorous (P) in soil. An air dried sandy loam soil was mixed with different amendments at rates equivalent to $0,200,400$ and $800 \mathrm{mg} \cdot P \cdot \mathrm{kg}^{-1}$ soil based on total P. The plant height and leaf number increased in the plants grown in amended pots compared to control pot. The dry weight of shoots and roots in the control pot were 14.3 and $2.8 \mathrm{~g}$, respectively. The shoot dry weights of corn increased from 43.8 to $76.6 \mathrm{~g}$ with the cow manure, 27.8 to $38.7 \mathrm{~g}$ with the city waste, 48.4 to $68.2 \mathrm{~g}$ with the chicken manure and 30.2 to $32.2 \mathrm{~g}$ with the TSP amendments when the P addition rates increased from 200 to $800 \mathrm{mg} \cdot \mathrm{P} \cdot \mathrm{kg}^{-1}$ soil. Similar effects of these amendments and their rates were also found in the case of roots dry weights production. Phosphorus concentration in the plant parts increased with the $\mathrm{P}$ application from different amendments but the increase was higher with the TSP fertilizer and lower with the city waste amendments. Olsen P (measured after the plant harvest) increased with P application rates. The extractability of Olsen $\mathrm{P}$ from different amendments increased in this order: city waste $<$ chicken manure $<$ cow manure $<$ TSP. Olsen $\mathrm{P}$ was strongly related with both shoot and root $\mathrm{P}$ concentration of corn $(\mathrm{r}=0.910, p=$ 0.000 ), indicate suitability of Olsen $P$ to predict plant available P. These results imply that cow manure and chicken manure could be recommended to use in the agricultural field for producing optimum yield.
\end{abstract}

Keywords: Organic Manure; Phosphate Fertilizer; Olsen P; Corn

\section{Introduction}

Phosphorus is an essential nutrient both as a part of several key plant structure compounds and as a catalysis in the conversion of numerous key biochemical reactions in plants. The total P content of most surface soils is low, averaging only $0.6 \% \mathrm{P}$. Soil $\mathrm{P}$ is classified in two broad groups, organic and inorganic. Organic $\mathrm{P}$ is found in plant residues, manures, and microbial tissues. Soils low in organic matter may contain about $3 \%$ of their total $\mathrm{P}$ in the organic form, but high organic matter (OM) soils may contain $50 \%$ or more of their total $\mathrm{P}$ content in the organic form [1]. Inorganic forms of soil P consist of apatite (the original source of all phosphorus), complexes of iron and aluminum phosphates, and $\mathrm{P}$ absorbed on clay particles. The solubility of these $\mathrm{P}$ compounds, as well as organic $\mathrm{P}$ is extremely low and only very small amounts of soil P are in solution at any one time. Most soils contain less than a pound per acre of soluble $P$, with some soils containing considerably less. Through adequate $\mathrm{P}$ fertilization and good crop/soil management, soil solution P can be replaced rapidly enough for optimum crop production [2].

*Corresponding author.
Rapidly rising prices of $\mathrm{P}$ fertilizers and the concern of high crop intensities in our country have stimulated the interest of using different types of organic amendments in our soils. Organic amendments contain considerable amounts of organic phosphorus which are mineralized (similar to organic nitrogen), and provide available phosphorus for plant growth. Unfortunately, OM status of Bangladesh soil is one of the lowest in the world. The average OM content of Bangladesh soils is less than 1\%, ranging between $0.05 \%$ and $0.9 \%$ in most cases. Organic matter supply in soil is one of the major constraints to the agriculture of the country and hence the release of $\mathrm{P}$ from $\mathrm{OM}$ is negligible [3]. Compost additions can improve the fertility and the physio-chemical properties of soils [4,5].

The availability of city wastes, cow and chicken manures $\mathrm{P}$ to crops and its impact on soil P pool may differ from that of inorganic P fertilizer [6-8]. McCoy et al. [8] found that biosolids (treated City wastes) $\mathrm{P}$ was four to seven times less available than triple super phosphate $\mathrm{P}$. In contrast, other studies have suggested that $\mathrm{P}$ in organic amendments may be equally or more available than fertilizer P $[9,10]$. Therefore, this study was conducted to 
investigate the effects of cow manure, city wastes, chicken manure and TSP on the growth of corn and phytoavailability of phosphorus in soils.

\section{Materials and Methods}

A pot experiment was conducted in the crop field of the Department of Soil Science, University of Chittagong using a Pahartoli Silty Clay Loam surface soil. Soil samples were collected, air dried and passed through 4-mm sieve for using it in the pots. For laboratory analysis, a sub sample was air dried and passed through a 2-mm sieve and stored. Soil pH was 5.1 (1:2.5 soil to water ratio), organic carbon [11] was $0.88 \%$ and CEC (extraction with $1 \mathrm{M}$ $\mathrm{NH}_{4} \mathrm{OAc}$ (pH 7.0; [12]) was $7.12 \mathrm{cmol} \cdot \mathrm{kg}^{-1}$. The soil contained $66 \%$ sand and $19 \%$ clay measured by hydrometer method [13]. Cow manure was collected from Chittagong University Campus, city waste from Ananda Bazar of Chittagong City, city and chicken manure was collected from the Veterinary and Animal Sciences University of Chittagong.

Five kilogram $(5 \mathrm{~kg})$ air dried soil were mixed with the cow manure, city waste, chicken manure and TSP at rates equivalent to $0,200,400,800 \mathrm{mg} \cdot \mathrm{P} \cdot \mathrm{kg}^{-1}$ soil, respectively based on total P. There were 13 treatments and each treatment was replicated three times. The pots were ar- ranged in a completely randomized design. Three corn (Zea mays) seeds were sown to each plastic $(70 \mathrm{~cm}$ in dia- meter) pot. One week after emergence, one seedling was kept in each pot. The plants were irrigated occasionally up to 30 days of sowing and from then onwards daily. The number of leaves and plant height were recorded at 30, 60 and 90 days of growth (at harvest). At 90 days of growth, plants were harvested, leaf number, maximum height of corn was recorded. Plants were separated into shoots and roots, and air dried for several days. After words, the shoots and roots were oven dried at $65^{\circ} \mathrm{C}$ for 72 hours and dry mass was recorded. Soil samples were collected from each pot after harvest to measure soil $\mathrm{pH}$ and $0.5 \mathrm{M} \mathrm{NaHCO}_{3}$ (Olsen P) extractable phosphorus.

Total phosphorous in the soil, organic amendments and in the plant tissues were determined colorimetrically by ascorbic acid blue color method [14] after digestion with $\mathrm{H}_{2} \mathrm{O}_{2}-\mathrm{H}_{2} \mathrm{SO}_{4}$ [15] and the absorbance was measured by spectrophotometer at wave length of $882 \mathrm{~nm}$. Total phosphorus concentration in the experimental soil was $0.04 \%$, in the cow manure was $0.35 \%$, in the city waste was $0.52 \%$ and in the chicken manure was $2.22 \%$. The available phosphorous of the soil were determined by the same procedure as mentioned above after extraction with $0.5 \mathrm{M}$ $\mathrm{NaHCO}_{3}[16]$.

\section{Statistical Analysis}

Microsoft Excel and MINITAB program [17] were used for analysis of variance and correlation.

\section{Rasults}

\subsection{Plant Growth}

Growth parameters (height, leaves number and dry weight) were influenced by amendments and increased significantly with $\mathrm{P}$ application rates. Mean height of corn plant at 30 to 90 days growing period increased from 42 to $94 \mathrm{~cm}, 83$ to $177 \mathrm{~cm}$ and 83 to $182 \mathrm{~cm}$, and the leaves number increased from 5 to 12,9 to 16 and 11 to 20 , respectively. Irrespective of amendments, the height of corn increased with the duration of growth from $75 \mathrm{~cm}$ at 30 days to $175 \mathrm{~cm}$ at 90 days in average. Similarly, the number of leaves also increased from 9 to 15 within the same growth period (Table 1). Dry weight of shoot increased from 14.3 to $76.6 \mathrm{~g}$ and of root from 2.8 to 21.1 g.pot ${ }^{-1}$. The highest dry weight of shoot and root was obtained with the cow manure treatment of $800 \mathrm{mg} \cdot \mathrm{P} \cdot \mathrm{kg}^{-1}$ and lowest with the control (T0) treatment. The second highest value was recorded in the chicken manure treatment $\left(800 \mathrm{mg} \cdot \mathrm{P} \cdot \mathrm{kg}^{-1}\right)$. The city waste and TSP produced similar dry matter yield. Growth performance was better in the cow manure amended soils than the other amendments (Table 1 and Table 2).

\subsection{Phosphorus Concentration in Plant Parts}

Phosphorus concentration in the shoots of corn increased with increasing the rates of $\mathrm{P}$ from different amendments. Phosphorus concentration in the shoot of control pot was the lowest of $554 \mathrm{mg} \cdot \mathrm{kg}^{-1}$ and the highest of $4525 \mathrm{mg} \cdot \mathrm{kg}^{-1}$ with TSP (800 $\mathrm{mg} \cdot \mathrm{P}^{\mathrm{kg}} \mathrm{kg}^{-1}$ treatment), while in the roots, the corresponding values were 628 and $3818 \mathrm{mg} \cdot \mathrm{kg}^{-1}$, respectively. Phosphorus concentration in the shoots of corn increased from 1682 to $2418 \mathrm{mg} \cdot \mathrm{P} \cdot \mathrm{kg}^{-1}$ in the cow manure, 1432 to $2629 \mathrm{mg} \cdot \mathrm{P}^{\mathrm{kg}} \mathrm{kg}^{-1}$ in the city waste, 1296 to $1707 \mathrm{mg} \cdot \mathrm{P} \cdot \mathrm{kg}^{-1}$ in the chicken manure and 2076 to $4525 \mathrm{mg} \cdot \mathrm{kg}^{-1}$ in the TSP fertilizer treated plants with the rates of $\mathrm{P}$ addition from 200 to $800 \mathrm{mg} \cdot \mathrm{kg}^{-1}$ soil. The same amendments increased root $\mathrm{P}$ concentration from 1442 to 2141,944 to 1938,720 to 1419 and 1578 to 3918 $\mathrm{mg} \cdot \mathrm{kg}^{-1}$ in the cow manure, city waste, chicken manure and in the TSP fertilizer treated pots (Table 2).

\subsection{5 $\mathrm{M} \mathrm{NaHCO}_{3}$ Extractable $\mathrm{P}$ and Soil $\mathrm{pH}$}

The amount of $\mathrm{P}$ extracted with $0.5 \mathrm{M} \mathrm{NaHCO}_{3}$ (Olsen P) followed the increasing trend of $\mathrm{P}$ additions from different amendments. It was observed that the Olsen $\mathrm{P}$ in the soils ranged from $3.66 \mathrm{mg} \cdot \mathrm{kg}^{-1}$ (Control) to $206 \mathrm{mg} \cdot \mathrm{kg}^{-1}$ (TSP $800 \mathrm{mg} \cdot \mathrm{kg}^{-1}$ ). It is evident that among the amendments, $\mathrm{NaHCO}_{3}$ extracted highest amount of P from TSP fertilizer amended soil and smallest amount from the city wasted amended soil. The P extractability from different amendments was in the order: TSP $>$ cow manure $>$ chicken manure > city waste. 
Table 1. Effect of different doses of cow manure, city waste, chicken manure and TSP on the height and leaf number of the plant at different days of growth.

\begin{tabular}{|c|c|c|c|c|c|c|}
\hline & \multicolumn{3}{|c|}{ Height of the plant at different days of growth $(\mathrm{cm})$} & \multicolumn{3}{|c|}{ Leaf number of the plant at different days of growth } \\
\hline & 30 & 60 & 90 & 30 & 60 & 90 \\
\hline Control (T0) & $42 \mathrm{c} \pm 6.0$ & $83 \mathrm{~d} \pm 11$ & $86 \mathrm{c} \pm 11$ & $5 c \pm 0.5$ & $9 \mathrm{~d} \pm 1.2$ & $11 b \pm 1.5$ \\
\hline Cow Manure 200 (T1) & $85 a \pm 10$ & $130 \mathrm{~b} \pm 8.6$ & $133 b \pm 7.6$ & $9 \mathrm{ab} \pm 1.2$ & $12 \mathrm{c} \pm 0.6$ & $14 \mathrm{~b} \pm 1.5$ \\
\hline Cow Manure 400 (T2) & $89 a \pm 7.8$ & $160 \mathrm{ab} \pm 14$ & $163 a \pm 13$ & $11 \mathrm{a} \pm 1.1$ & $16 b \pm 1.7$ & $18 \mathrm{ab} \pm 1.2$ \\
\hline Cow Manure 800 (T3) & $94 \mathrm{a} \pm 4.2$ & $177 \mathrm{a} \pm 1.2$ & $182 \mathrm{a} \pm 5.1$ & $12 \mathrm{a} \pm 1.7$ & $17 \mathrm{a} \pm 0.6$ & $20 \mathrm{a} \pm 1.0$ \\
\hline City Waste 200 (T4) & $55 \mathrm{bc} \pm 13$ & $128 b c \pm 15$ & $130 \mathrm{~b} \pm 13$ & $7 \mathrm{bc} \pm 1.0$ & $11 \mathrm{~cd} \pm 0.7$ & $13 \mathrm{~b} \pm 2.1$ \\
\hline City Waste 400 (T5) & $64 \mathrm{bc} \pm 7.6$ & $134 \mathrm{ab} \pm 6.3$ & $137 b \pm 5.6$ & $7 \mathrm{c} \pm 1.2$ & $12 \mathrm{c} \pm 0.6$ & $13 \mathrm{~b} \pm 1.5$ \\
\hline City Waste 800 (T6) & $55 b c \pm 19$ & $116 c \pm 23$ & $127 b \pm 13$ & $8 b c \pm 2.1$ & $14 b \pm 1.9$ & $15 b \pm 2.9$ \\
\hline Chicken Manure 200 (T7) & $75 \mathrm{ab} \pm 6.8$ & $162 \mathrm{a} \pm 9.7$ & $163 a \pm 11$ & $8 \mathrm{bc} \pm 2.0$ & $12 c \pm 0.5$ & $13 \mathrm{~b} \pm 0.6$ \\
\hline Chicken Manure 400 (T8) & $79 \mathrm{ab} \pm 6.4$ & $153 a b \pm 8.7$ & $156 \mathrm{ab} \pm 10$ & $9 \mathrm{ab} \pm 1.2$ & $14 \mathrm{bc} \pm 0.9$ & $16 b \pm 1.1$ \\
\hline Chicken Manure 800 (T9) & $80 \mathrm{ab} \pm 10$ & $165 \mathrm{a} \pm 10$ & $173 a \pm 12$ & $10 \mathrm{ab} \pm 1.5$ & $15 b \pm 0.6$ & $17 \mathrm{~b} \pm 0.6$ \\
\hline TSP 200 (T10) & $88 \mathrm{ab} \pm 5.7$ & $121 b c \pm 5.9$ & $121 b \pm 5.3$ & $9 \mathrm{ab} \pm 0.5$ & $13 c d \pm 0.7$ & $15 b \pm 1.0$ \\
\hline TSP 400 (T11) & $88 \mathrm{ab} \pm 4.0$ & $117 b c \pm 3.2$ & $118 b \pm 3.1$ & $11 \mathrm{a} \pm 1.5$ & $14 \mathrm{c} \pm 1.0$ & $16 \mathrm{~b} \pm 1.0$ \\
\hline TSP 800 (T12) & $78 \mathrm{ab} \pm 14$ & $128 b c \pm 8.5$ & $128 b \pm 8.1$ & $11 \mathrm{a} \pm 1.1$ & $15 c \pm 0.8$ & $16 \mathrm{~b} \pm 1.2$ \\
\hline Mean & 75 & 136 & 139 & 9 & 13 & 15 \\
\hline
\end{tabular}

Means followed by the same letter (s) in a column is not significantly different at $\mathrm{p}<0.05$ level, \pm denotes standard deviation.

Table 2. Effect of different doses of cow manure, city waste, chicken manure and TSP on the dry weight and P concentrations of shoot and roots, Olsen $P$ and soil $\mathrm{pH}$.

\begin{tabular}{|c|c|c|c|c|c|c|}
\hline & \multicolumn{2}{|c|}{$\begin{array}{l}\text { Dry weight of shoot and } \\
\text { root of corn }\left(\mathrm{g} \cdot \text { plant }^{-1}\right)\end{array}$} & \multicolumn{2}{|c|}{$\begin{array}{l}\text { Phosphorus concentration in shoot } \\
\text { and in root of plant }\left(\mathrm{mg} \cdot \mathrm{kg}^{-1}\right)\end{array}$} & \multirow{2}{*}{$\begin{array}{l}\text { Olsen } \mathrm{P} \text { in soil } \\
\left(\mathrm{mg} \cdot \mathrm{kg}^{-1}\right)\end{array}$} & \multirow{2}{*}{ Soil pH } \\
\hline & Shoot & Root & Shoot & Root & & \\
\hline Control (T0) & $14.25 d \pm 2.6$ & $2.75 \mathrm{~d} \pm 0.6$ & $554 \mathrm{e} \pm 70$ & $628 \mathrm{e} \pm 41$ & $4.3 f \pm 1.3$ & $5.3 f \pm 0.05$ \\
\hline Cow Manure 200 (T1) & $43.78 c \pm 5.2$ & $11.72 b \pm 1.1$ & $1682 d \pm 242$ & $1442 \mathrm{~cd} \pm 236$ & $33.7 e \pm 3.8$ & $5.6 e \pm 0.09$ \\
\hline Cow Manure 400 (T2) & $59.58 b \pm 2.3$ & $16.91 \mathrm{a} \pm 1.8$ & $1914 \mathrm{~cd} \pm 253$ & $1805 \mathrm{~cd} \pm 303$ & $55.9 d \pm 3.6$ & $5.8 e \pm 0.05$ \\
\hline Cow Manure 800 (T3) & $76.57 \mathrm{a} \pm 4.9$ & $21.09 \mathrm{a} \pm 2.5$ & $2418 b c \pm 35$ & $2141 b c \pm 253$ & $69.9 \mathrm{c} \pm 7.1$ & $6.1 \mathrm{~d} \pm 0.06$ \\
\hline City Waste 200 (T4) & $27.86 \mathrm{c} \pm 2.8$ & $3.87 \mathrm{~d} \pm 0.4$ & $1432 \mathrm{~d} \pm 161$ & 944de \pm 213 & $16.6 \mathrm{e} \pm 2.3$ & $6.5 b \pm 0.13$ \\
\hline City Waste 400 (T5) & $32.33 c \pm 1.3$ & $5.28 \mathrm{~d} \pm 1.0$ & $1671 d \pm 193$ & 1280de \pm 181 & $21.2 \mathrm{e} \pm 2.1$ & $6.8 \mathrm{a} \pm 0.08$ \\
\hline City Waste 800 (T6) & $38.71 \mathrm{c} \pm 2.8$ & $6.89 \mathrm{~cd} \pm 0.8$ & 2629 c \pm 419 & $1938 \mathrm{~cd} \pm 130$ & $28.1 \mathrm{e} \pm 0.6$ & $6.9 \mathrm{a} \pm 0.32$ \\
\hline Chicken Manure 200 (T7) & $48.40 \mathrm{bc} \pm 4.1$ & $9.27 b c \pm 1.3$ & $1296 \mathrm{~d} \pm 40$ & $720 \mathrm{e} \pm 82$ & $12.3 \mathrm{ef} \pm 2.2$ & $6.4 \mathrm{c} \pm 0.17$ \\
\hline Chicken Manure 400 (T8) & $58.13 b \pm 2.1$ & $11.63 b \pm 0.8$ & $1454 d \pm 68$ & 971de \pm 124 & $28.4 \mathrm{e} \pm 2.3$ & $6.7 b \pm 0.06$ \\
\hline Chicken Manure 800 (T9) & $68.20 \mathrm{a} \pm 1.6$ & $14.28 b \pm 0.9$ & $1707 d \pm 202$ & 1419de \pm 313 & $55.2 d \pm 2.6$ & $7.1 \mathrm{a} \pm 0.07$ \\
\hline TSP 200 (T10) & $30.15 c \pm 2.4$ & $4.33 d \pm 0.3$ & $2076 \mathrm{~cd} \pm 184$ & 1578 cde \pm 143 & $68.9 c \pm 0.9$ & $5.5 \mathrm{ef} \pm 0.06$ \\
\hline TSP 400 (T11) & $32.05 c \pm 5.5$ & $3.60 \mathrm{~d} \pm .8$ & $3044 b \pm 263$ & $2013 b c \pm 376$ & $126 b \pm 8.1$ & $5.6 \mathrm{e} \pm 0.06$ \\
\hline TSP 800 (T12) & $30.62 \mathrm{c} \pm 3.8$ & $3.87 \mathrm{~d} \pm 1.0$ & $4525 a \pm 686$ & $3918 a \pm 262$ & $206 a \pm 6.9$ & $5.5 e \pm 0.08$ \\
\hline
\end{tabular}

Means followed by the same letter (s) in a column is not significantly different at $\mathrm{p}<0.05$ level, \pm denotes standard deviation. 
After the harvest, $\mathrm{pH}$ measured in the control soil was 5.36, while it increased from 5.57 to $6.05,6.48$ to 6.93 , 6.38 to 7.06 and 5.48 to 5.53 in the cow manure, city waste, chicken manure and TSP fertilizer treated soils when the rates of $\mathrm{P}$ added from 200 to $800 \mathrm{mg} \cdot \mathrm{P} \cdot \mathrm{kg}^{-1}$ soil from different amendments. Among the amendments, the hi- ghest changes of $\mathrm{pH}$ was observed in the chicken manure treated soil and lowest in the TSP fertilizer treated soil, however, $\mathrm{pH}$ changes were almost similar in city waste and chicken manure treated soil.

Correlation coefficient of $\mathrm{P}$ concentration of shoot and root of corn with Olsen $\mathrm{P}$ of soil was calculated to find out the relationship among them. Olsen $\mathrm{P}$ showed very strong positive correlation with both shoot and root $\mathrm{P}$ concentration ( $\mathrm{r}=0.910, p=0.000)$ which indicating suitability of Olsen $\mathrm{P}$ to predict plant available P (Figure 1). Soil $\mathrm{pH}$ did not show any relationship with dry matter yield, plant $\mathrm{P}$ concentration and with Olsen $\mathrm{P}$ in soil.

\section{Discussion}

The higher increase in plant growth in the cow and chicken manure treated soils than the TSP treated soil might be due to the improved soil physical, chemical and biological properties that enhanced plant growth and soil $\mathrm{pH}$.
The rise in productivity observed after addition of compost is attributed to the increase in the nutrient availability to the plants $[4,5,18]$. Metal phytotoxicity issues associated with an acid soil would also be reduced with compost addition $[4,19]$. Phosphorus concentration in the plant parts increased linearly with rates irrespective of amendments. It is evident from the result on $\mathrm{P}$ content under different treatments that application of TSP is more effective when $\mathrm{P}$ uptake is concern. Higher content of $\mathrm{P}$ in shoot and root under TSP $800 \mathrm{mg} \cdot \mathrm{kg}^{-1}$ and TSP $400 \mathrm{mg} \cdot \mathrm{kg}^{-1}$ is logical as TSP is soluble and immediately supply soluble $\mathrm{P}$ for immediate plant uptake and accumulation [20].

\section{Conclusion}

The rates of $\mathrm{P}$ addition from different amendments increased biomass production of corn significantly except the TSP fertilizer. The TSP fertilizer addition only increased plant P concentration not the growth as did other organic amendments. Higher biomass production in the organic amendments, especially in the cow manure and chicken manure treatments indicate that they provided other essential nutrients beside $\mathrm{P}$ and hence growth increased. The results imply that cow manure and chicken
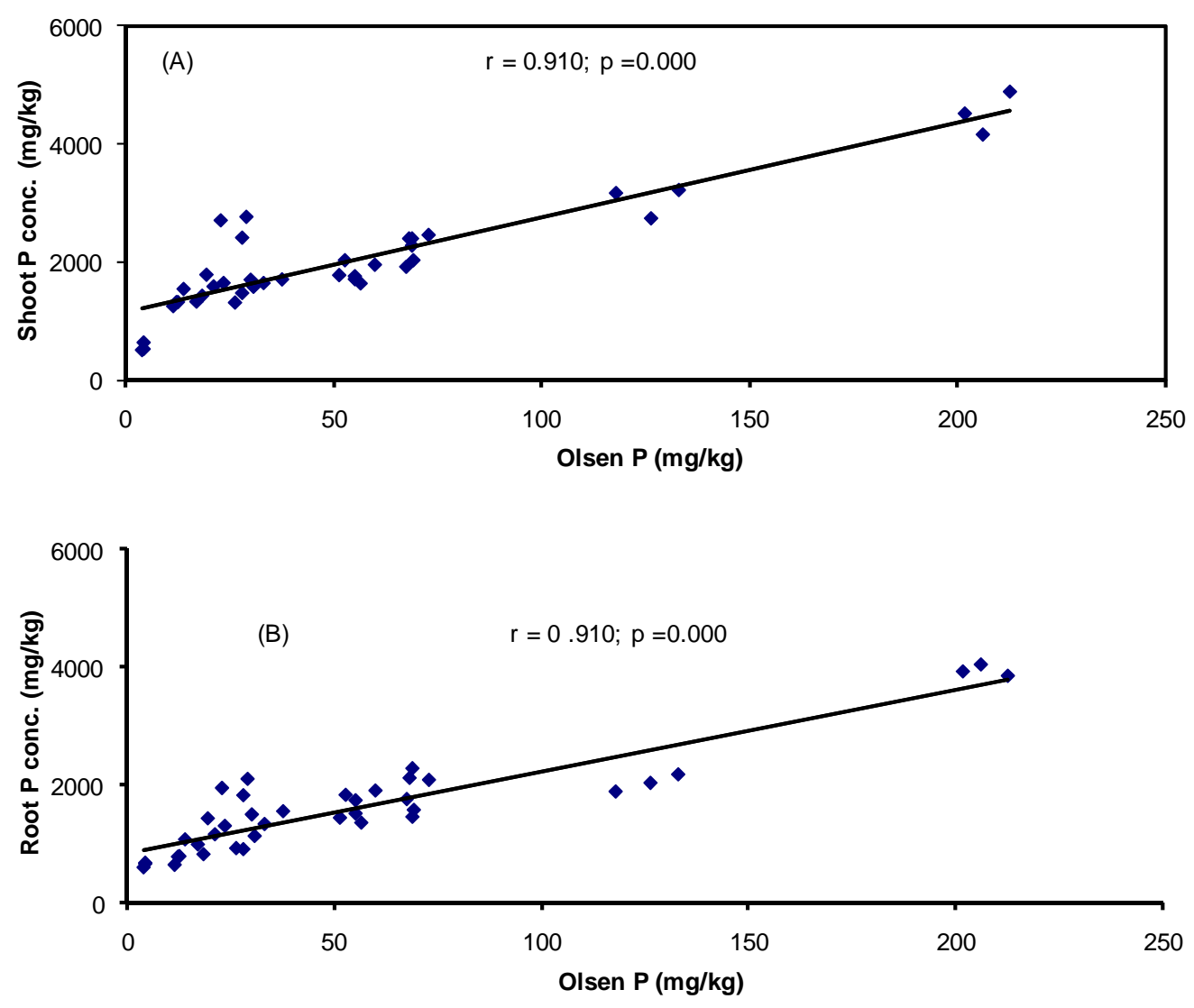

Figure 1. Correlation between (A) Shoot $P$ and Olsen $P$ and between (B) Root $P$ and Olsen $P$. 
manure could be recommended to use in the agricultural field for producing optimum yield when additional chemical fertilizers are not applied.

\section{REFERENCES}

[1] B. Griffith, “Efficient Fertilizer Use Manual,” 2011. http://www.back-to-basics.net/efu/pdfs/Phosphorus.pdf.

[2] E. F. Khasawneh, E. C. Sample and E. J. Kamprath, "The Role of Phosphorus in Agriculture,” American Society of Agronomy, Crop Science Society of America, and Soil Science Society of America, Madison, 1980.

[3] Banglapedia, "Soil Fertility,” 2012. http://www.banglapedia.org/HT/S_0460.HTM

[4] M. A. Kashem and B. R. Singh, "Metal Availability in Contaminated Soils: II. Uptake of Cd, Ni and $\mathrm{Zn}$ in Rice Plants as Affected by Moisture Level and Organic Matter”, Nutrient Cycling in Agroecosystems, Vol. 61, No. 3, 2001, pp. 257-266. doi:10.1023/A:1013724521349

[5] V. D. Zheljazkov and P. R. Warman, "Application of High Cu Compost to Swiss Chard and Basil,” Science of Total Environment, Vol. 302, No. 1-3, 2003, pp. 13-26.

[6] M. A. Kashem, O. O. Akinremi and G. J. Rez, "Phosphorus Fraction in Soil Amended with Organic and Inorganic P Sources," Canadian Journal of Soil Science, Vol. 84, No. 1, 2004, pp. 83-90. doi:10.4141/S03-018

[7] M. A. Kashem, O. O. Akinremi and G. J. Rez, "Extractable Phosphorus in Alkaline Soils Amended with High Rates of Organic Amendments," Canadian Journal of Soil Science, Vol. 84, No. 4, 2004, pp. 459-467. doi:10.4141/S03-085

[8] J. L. McCoy, L. J. Sikora and R. R. Weil, "Plant Availability of Phosphorus in Sewage Sludge Compost," Journal of Environmental Quality, Vol. 15, No. 4, 1986, pp. 403-409. doi:10.2134/jeq1986.00472425001500040016x

[9] P. M. Gale, M. D. Mullen, C. Cieslik, D .D. Tyle, B. N. Duck, M. Kirchner and J. McClure, "Phosphorus Distribution and Availability in Response to Dairy Manure Applications," Communications in Soil Science and Plant Analysis, Vol. 31, No. 5-6, 2000, pp. 553-565. doi:10.1080/00103620009370459

[10] B. D. Meek, L. E. Graham, T. J. Donovan and K. S. Mayberry, "Phosphorus Availability in Calcareous Soil after
High Loading Rates of Animal Manure,” Soil Science Society of American Journal, Vol. 43, No. 4, 1979, pp. 741743. doi:10.2136/sssaj1979.03615995004300040024x

[11] A. Walkley and I. A. Black, "An Examination of Degtjareff Method for Determining Soil Organic Matter and a Proposed Modification of the Chromic Acid Titration Method,” Soil Science, Vol. 37, No. 1, 1934, pp. 29-38. doi:10.1097/00010694-193401000-00003

[12] Soil Survey Laboratory Staff, "Soil Survey Laboratory Methods Manual,” Soils Survey Investigation Report, Washington DC, 1992.

[13] G. J. Bouyoucos, "Hydrometer Method Improved for Making Particle Size Analysis of Soils," Agronomy Journal, Vol. 54, No. 5, 1962, pp. 464-465. doi:10.2134/agronj1962.00021962005400050028x

[14] J. Murphy and J. P. Riley, “A Modified Single Solution Methods for the Determination of Available Phosphate in Natural Water," Analytica Chimica Acta, Vol. 27, 1962, pp. 31-36.doi:10.1016/S0003-2670(00)88444-5

[15] O. O. Akinremi, N. Amisen, M. A. Kashem and H. H. Janzen, "Evaluation of Analytical Methods for Total P in Organic Amendments,” Communications in Soil Science and Plant Analysis, Vol. 34, No. 19-20, 2003, pp. 29812991.doi:10.1081/CSS-120025220

[16] S. R. Olsen, C. V. Cole, F. S. Watanabe and L. A. Dean, "Estimation of Available Phosphorus in Soils by Extraction with Sodium Bicarbonate,” U.S. Government Printing Office, Washington DC, 1954.

[17] Minitab Inc., “Minitab User Guide Release 11,” Minitab, State College, 1996.

[18] M. A. Kashem and P. R. Warman, "Effect of Application of Chromium Feedstock Compost on the Growth and Bioavailability of Some Trace Elements in Lettuce," Communications in Soil Science and Plant Analysis, Vol. 40, No. 15-16, 2009, pp. 2426-2439. doi:10.1080/00103620903111327

[19] N. V. Hue and I. Amien, "Aluminium Detoxification with Green Manure,” Communications in Soil Science and Plant Analysis, Vol. 20, No. 15-16, 1989, pp. 1499-1511. doi:10.1080/00103628909368164

[20] S. L. Tisdale, W. L. Nelson and J. D. Beatom, "Soil Fertility and Fertilizers," 4th Edition, Macmillan Publishing Company, New York, 1985. 